\title{
Environmental causes and impacts of the genocide in Rwanda: Case studies of the towns of Butare and Cyangugu
}

\section{Vadi Moodley, Alphonse Gahima and Suveshnee Munien*}

\section{Abstract}

The history of the world has always been punctuated by cycles of violence, regardless of time, region or race. Genocide, which is one of the worst forms of violence, has always led to horrific socio-economic and environmental impacts. The last decade of the $20^{\text {th }}$ century was the most turbulent Rwanda has ever experienced in its history. The country was ravaged by civil war, genocide, mass migrations, economic crisis, diseases, return of refugees and environmental destruction. Rwandan families were affected by and are still dealing with impacts such as death, disease, disability, poverty, loss of dignity and imprisonment. This paper uses a geographical perspective, more specifically the geography of conflict, to assess the environmental causes and impacts of the genocide in Rwanda, more than a decade after the genocide. Primary data used in this article were obtained from fieldwork undertaken in Cyangugu and Butare Towns, case studies chosen not only because of their particular history

* Dr Vadi Moodley is senior lecturer at the University of KwaZulu-Natal, Durban.

Mr Alphonse Gahima is lecturer at the Marist International College, Nairobi, Kenya (completed his Masters degree under the supervision of Dr Vadi Moodley, University of KwaZulu-Natal).

Miss Suveshnee Munien is temporary lecturer at the University of KwaZulu-Natal, Durban. 
before, during and after the genocide but also because of their heterogeneous population and physical landscapes. Empirical evidence obtained and secondary data sources indicate that the genocide in Rwanda destroyed not only human resources and social and cultural structures but also infrastructure, development facilities and natural resources which had serious negative consequences on the total environment.

\section{Introduction}

Known poetically as the 'Land of a Thousand Hills' due to its relief, Rwanda is a tiny, landlocked republic lying south of the equator in East-Central Africa (World Bank 2004:20) and lies between (roughly) $1^{\circ} \mathrm{S}$ and $3^{\circ} \mathrm{S}$, and $29^{\circ} \mathrm{E}$ and $31^{\circ} \mathrm{E}$ (Central Intelligence Agency: The World Factbook 2002:356). The country is bounded by Lake Kivu and the Rusizi River on the west; on the south by the Ruhwa and Akanyaru Rivers; on the east by the Akagera River; and on the northwest by a chain of volcanoes. Rwanda's neighbours are Uganda to the north, Burundi to the south, Tanzania to the east and the Democratic Republic of the Congo to the west and northwest (MINECOFIN 2002:344). It had a population size of 9,6 million in 2008 (PRB 2009:4). The land area is 26338 square kilometres (World Bank 2004:20) with a high population density of 365 per square kilometre (PRB 2009:4). It is one of the most densely populated countries on the African continent with population pressure on scarce land threatening the physical environment and the social harmony in the country (World Bank 2004:20).

In the last decade of the $20^{\text {th }}$ century almost every Rwandan household was affected by at least one of the following: economic crises, civil war, internal displacement, mass emigration, political transition, returning refugees, destruction of natural resources and most importantly the genocide (Verwimp and Baval 2005:272). Moreover, the environmental degradation caused by the massive population displacements caused vast economic losses to the country. The government made serious efforts to resettle people by making more land available. However, this resulted in biodiversity and natural resources being destroyed. Forests and woodlands came under strain as is evidenced by the reduction in area of the Nyungwe and Akagera National Forests after the 


\section{Environmental causes and impacts of the genocide in Rwanda}

genocide (REMA 2009:86-87). According to Gahima (2007:4), although there has been a proliferation of research on Rwanda by scholars who go beyond simply describing the political and historical causes of the genocide as a result of the hatred between the Hutu and Tutsi ethnic groups, there have been few attempts to assess the voices of people and leaders on the environmental impacts of the genocide in their daily lives (Gahima 2007). It is also clear that environmental impacts cannot be discussed in isolation from the socio-economic and political dynamics in the country and the backdrop of the genocide itself. This article will attempt to fill this gap, using primary and secondary information sources to satisfy the following objectives: (1) to provide a conceptual basis by discussing genocides and conflicts; and (2) to evaluate the environmental impacts of the genocide. Empirical data were obtained from two case studies from a larger study that focused on the social and environmental impacts of the genocide. The case studies are from different historical and geographic areas, the semiurban towns of Butare and Cyangugu in Rwanda. Butare was chosen due to the large number of people killed (100 000 according to Melvern 2000:171), and Cyangugu because it was an environment that was most affected by the genocide. In this area destruction lasted longer than in other parts of the country, and there was a massive return of refugees and the emergence of grouped settlements (Imidugudu) established by the state (Ministry of Infrastructures 2004:23).

In both areas, a representative sample of 100 residents was drawn from the population by using multistage sampling techniques. Stratified random sampling was the most appropriate technique. Within each town, a stratified sample of two subgroups was selected according to location and socio-economic status. One subgroup was comprised of high-income residents, living in a suburban area and the other subgroup was from a semi-urban area with low-income residents, living in modest housing. Within these two subgroups, two cells were selected randomly. From each cell a random sample of 25 households was chosen. In total, there were four cells chosen which made up the 100 residents for the study. Community leaders, one from each of the four cells, were purposively selected and semi-structured questionnaires were used in these interviews. The questionnaire at the household level focused on attitudes, perceptions and experiences on issues pertaining to their lives including the environment before 
and after the genocide, whilst that for the leaders was based on infrastructure and environmental management in their administrative units after the genocide.

To better understand the environmental causes and impacts of the genocide and to determine the contextual basis of the discussion that follows, a brief overview of genocides and conflicts will be discussed. The next section will discuss environmental issues based on primary data from the survey and secondary sources. However, due to the multiple aspects comprising the environment, the focus in this article has been narrowed down to a few key dimensions that had significant impacts on the environment - destruction of biodiversity, deforestation, farming and agricultural activities, housing and the construction of new facilities, fuel and energy sources and the spread of malaria due to deforestation.

\section{Conflicts and Genocides}

\section{Conflicts}

Laue (1993:256) defined conflict as 'escalated natural competition between two or more parties about scarce resources, power and prestige'. Parties in conflict believe they have incompatible goals, and their aim is to neutralise, gain advantage over, injure or destroy one another (Laue 1993:257). According to Fry and Bjorkqvist (1997:26), conflict, although inevitable, is not inherently pathological, sick behaviour or always dysfunctional. Some conflicts are harmful but they may, in some cases, improve society and social relations on a longterm basis. Conflict can be a constructive force in social life (Fry and Bjorkqvist 1997:26). Toft (2004) in his book 'The geography of ethnic violence: Identity, interests and the indivisibility of territory' approached the issue of conflicts and genocide in particular within the geography of ethnic violence and argues that conflicts are complex phenomena which are the results of either socio-political, economic or environmental disintegration. Turshen (2001:57) emphasised, for instance, the world market and massive poverty as the roots of genocide in addition to the colonial legacy and the indifference of Western ruling classes. The theoretical links between geography, society and conflicts were also 


\section{Environmental causes and impacts of the genocide in Rwanda}

highlighted by Ferguson (1994:59) who emphasised that genocides had negative consequences on the infrastructure, structure and superstructure.

\section{Genocide}

According to the United Nations (cited in Destexhe 1996:5), genocide

...means any of the following acts committed with intent to destroy, in whole or in part, a national, ethnic, racial or religious group, including (a) killing members of the group (b) causing serious bodily or mental harm to members of the group (c) deliberately inflicting on the group conditions of life calculated to bring about its physical destruction in whole or in part (d) imposing measures intended to prevent births within the group by forcibly transferring children of the group to another group.

This terminology has been reviewed and enriched and even subjected to controversies by social scientists who have shown that all mass murders or massacres are not necessarily genocide (Staub 1992:8), but one can also conceive genocide where there is no murder (Robbins and Robbins 2003:151). Genocide as stated by McCullum (1995:105) is deliberate murder born of the myth that one ethnic group, race or creed is superior to another and that it is thus legitimate to eliminate that 'other' to gain power. Calvocoressi (2005:656) states that the massacres of the 1990s in Rwanda were the clearest instances of genocide since the adoption in 1948 of the genocide convention by the United Nations (UN). However, some scholars have a number of problems with the UN definition. Chalk and Jonassohn (1990:10-11) argue that the UN definition 'is responsible for much of the confusion that plagues scholarly work in the field' because it lacks rigour.

Muberanziza (2004:6) contends that when an act is committed with the intention to destroy a group in whole or in part it constitutes genocide and the number of victims does not matter. According to Destexhe (1996:4), 'the specificity of genocide does not arise from the extent of the killings'. For Staub (1992:8) the notion of mass killing is no longer enough to define genocide. It is also argued that genocide may or may not consist of murder. One can conceive of genocide 


\section{Vadi Moodley, Alphonse Gahima and Suveshnee Munien}

where there is no murder but other acts such as rape and torture which do not kill or cause the deaths of members of a group (Robbins and Robbins 2003:151). Genocide may include the purposeful submission of a group to conditions of existence leading to total or partial physical destruction. For example, the deprivation of food and health care can be seen as an act of genocide (Mann 2005:4; Muberanziza 2004:6). Genocide can also consist of measures aimed at hindering births or the transfer of children of one group to another, and attacks on the physical and mental integrity of victims (Muberanziza 2004:6). Some scholars such as Mann (2005:4) have underlined the role of the State in carrying out genocide and the responsibility of the international community in acknowledging its occurrence.

Thus scholars have improved our understanding of genocides and went beyond the simple description of ancient hatred as their main cause (Mamdani 2001; Melvern 2000; Naimak 2001; Nyankanzi 1999; Pottier 2002; Prunier 1995; Staub 1992). The work by Nyankanzi (1999) showed for instance that all genocides were not ethnically or racially based. Mamdani (2001:9-20) attempted to understand the dynamics behind the slaughter by exploring the difference between settlers and natives which has made the causes of genocide in general and in Rwanda in particular much easier to understand.

\section{Causes of genocides}

\section{Socio-political}

There is no common cause of genocide; it all depends on the different historical background of each country and how perpetrators define the group and how they determine who is a member (Karen 1996:6). On the Asian continent, communism as a socio-political and economic doctrine was the context in which genocide occurred, notably in Cambodia and China (Destexhe 1996:19). The Khmer Rouge communist leaders in Cambodia combined extremist ideology with ethnic animosity and disregarded human life to repress and murder and cause misery on a massive scale (Chalk and Jonassohn 1990:270). In Africa genocide and the strategy of dividing people in colonies were used to conquer and exploit people and gain economic and political power (Mann 2005:428). In 


\section{Environmental causes and impacts of the genocide in Rwanda}

the case of Rwanda, genocide was a carefully planned and executed exercise to annihilate Rwanda's Tutsi and Hutu populations who disagreed with extremist politics. Here, genocide had much more complex roots than just deep ethnic hatred (Keane 1995:8; Melvern 2000:11). Its main causes were socio-political. They were rooted in the manipulation of the history of Rwanda by both colonial and post-colonial leaders and can therefore be attributed to both internal and external factors. The history of Rwanda was manipulated before independence by Western colonisers (Germany and Belgium) and after independence by inefficient local leadership (Turshen 2001:57) and the failure of democracy (Mann 2005:4). International indifference and the involvement of some Western countries who are accomplices made it possible for genocide to occur (Barnett 2005:551).

\section{Economic}

Economic factors have also shaped and worsened the effects and the extent of the genocide (Utterwulghe 1999). Turshen (2001:57-58) notes that four socioeconomic factors shaped the extent of genocide: (1) the abrupt drop in the price of coffee, coupled with a 1989 currency devaluation and rapid inflation after 1990; (2) a structural adjustment programme combined with a drought in the southern regions which turned into a famine; (3) the war in the north (1990) that drained government resources and created huge refugee camps in the north of Kigali; and (4) the 'paradox of democratisation in Africa' which caused opposition to the already embattled government.

\section{Cultural}

The roots of violence in Rwanda are 'more complex than most people had imagined' and the terms Hutus and Tutsis refer to constructed categories of different socio-economic positions within Rwandan society (Jennings 2001:65). Melvern (2000:11) states that these two ethnic groups shared the same language, culture and lived in the same village with intermarrying and people exchanging identities. A 'pure ethnic divide is a myth' (Melvern 2000:11). According to Mamdani (2001:9-20), it was the Belgian reform of the colonial State in the decade from the mid-1920s to the mid-1930s that established Hutus 
as indigenous Bantu and Tutsis as alien Hamites. This Hamitic hypothesis, he argues, explained away every sign of civilisation in tropical Africa as a foreign import. Hutu and Tutsi became political identities connected to the origins of the violence (Mamdani 2001:9-20).

The Rwandan genocide 'was not a simple matter of mutual hatred between tribes erupting into irrational violence' (Keane 1995:7). Documentary evidence shows that the killings were planned in advance by a clique (family and in-laws) close to President Habyarimana who resented power-sharing with the Tutsi (Melvern 2000:42-43; Keane 1995:10). According to Pottier (2002:9), 'Rwanda's bloodbath was not tribal. It was rather a distinctly modern tragedy, a degenerated class conflict minutely prepared and callously executed' which the world failed to see. This indicates the complexity of the genocide in Rwanda and suggests that if class (related to resource access as well) issues are not adequately addressed, the prospect of another genocide exists.

\section{Environmental Factors}

Environmental factors also played a key role in shaping the genocide. Rwanda, is a small country whose population increased from 1887000 in 1948 to more than 7500000 in 1992 (IRIN 2002). Such a high population within a small land area makes it one of the most densely populated countries in Africa (IRIN 2002). Population densities range between 310 (UNDP 2003:3) to 410 (Pan African News Agency 2000) inhabitants per square kilometre. There is no doubt that Rwanda's overpopulation and poverty problems somehow lay at the heart of increasing ethnic tensions. As the population grew and sub-divisions amongst family members increased, the amount of available land for subsistence purposes decreased drastically, leaving many landless and unemployed. As a result, people were easily encouraged by political leaders to kill the Tutsis so that they could take possession of their land (African Rights 1995:6). African Rights (1995:6) state that 'the men who planned and implemented the genocide, called upon the population to loot the property of Tutsis, the people marked out for extinction as a principal strategy for encouraging mass participation in the slaughter'. Land, therefore, became an object of lasting conflict not only in Rwanda but also in other African countries (Robbins and Robbins 2003:73). This manipulation by 


\section{Environmental causes and impacts of the genocide in Rwanda}

the Habyarimana regime through its policies is clearly evident in Boudreaux's (2009) article on 'Land Conflict and Genocide in Rwanda' as discussed below.

Boudreaux's (2009:85) critical review of Diamond's (2005) book 'Collapse' in her article provides some useful insights on why Rwanda is not 'a modern day Malthusian Crisis'. Diamond, she contends, did not consider the reasons for Rwandans being tied to their land. These are:

Lack of a formal market that would allow people to sell land and move to more urbanised areas, government policies that limited the movement of citizens from the countryside to urban centres, tightly controlled markets that limited entrepreneurial opportunities for people who might wish to leave farms, and a general pro-rural ideology imposed by the pre-genocide Habyarimana government (Boudreaux 2009:85).

She further contends that land conflict was not the primary impetus for violence and genocide, but that government policies limiting land sales, freedom of movement and labour opportunities as well as non-use of family planning and mismanagement of conflicts in a peaceful way were factors that led to the discontent of people in the country (Boudreaux 2009:85).

The problem of small land is certainly not enough to explain the atrocities which took place in Rwanda. Countries such as Belgium and Swaziland are as small as Rwanda, but they never experienced genocide. Thus poverty, overpopulation and unemployment are not the determinant causes of the genocide in Rwanda but are among factors which facilitated the recruitment of militias among young people, who had nothing to lose, just before 1994 (Semelin 2005:26-30). According to African Rights (1995:6), a superficial analysis of the genocide would blame poverty, overpopulation, the environmental and economic crisis for the tensions which led to the killings. They also contend that possible reasons lie within the socio-political structures that manipulated people from sources of resentment and despair to commit acts of violence (African Rights 1995:6). Briefly, the roots of the Rwandan genocide lie in the country's colonial legacy, misunderstanding of democracy and other indirect factors such as the working 
of the world market, massive poverty, class divisions within the Rwandan society, and the cynical indifference of the Western ruling classes (Melvern 2000:11-12).

\section{Environmental impacts}

\section{State of biodiversity}

Rwanda is part of the Albertine Rift eco-region and is considered a biological hotspot. It contains a variety of endemic mammals, birds, butterflies, fish and amphibians (REMA 2009:67). The demands of high population densities and increased land shortages have resulted in large-scale conversion of natural habitats for mining, agriculture and human activities (REMA 2009:72). Because natural resources are becoming scarce, poaching of several species, including mountain gorilla, buck and elephant for trade and consumption is increasing. The biological hotspots in the country are further stressed due to the large numbers of refugees and returnees in the post-genocide camps and resettlement plots, increased competition for and reliance on the natural environment for basic survival (REMA 2009:73). The country has also lost wetland biodiversity (UNEP and IISD 2005:3). The loss of this valuable asset is due to extensive drainage and irrigation, reclamation for rice production, sugar cane growing and grazing of livestock during the dry season (REMA 2009:77). This has caused devastation of the environment leading to environmental degradation.

\section{Deforestation}

Natural forests have covered $36 \%$ of the country but since 1990 forest have declined by 78\% (UNEP and IISD 2005:3). In 1960 the forest cover was 607000 ha but by 1995 it decreased to 221000 ha and deforestation is growing at a rate of $7 \%$ per annum since the genocide (Niyongabo 2004:27). The country has one of the highest deforestation rates in Central Africa (UNEP and IISD 2005:3). This is largely due to the scarcity of land which is a critical issue and may have been a contributory factor for the genocide. Landless people comprise 11,5\% of the population and about $29 \%$ possess less than 0,2 ha of land and $60 \%$ less than 0,5 ha (Niyongabo 2004:26). Land demand is high in Rwanda and issues of limited access may fuel further conflict. 


\section{Environmental causes and impacts of the genocide in Rwanda}

After the genocide mass clearing and removal of forests took place. This was for the purpose of making more land available for the relocation of refugees and displaced persons, firewood, logging for settlements and road construction. Additionally overgrazing and cultivation have led to deforestation (UNEP and IISD 2005:3). From 1993 to 2006 protected areas have been reduced by $92 \%$ (PRB 2009:6). For example, the Akagera National Park as well as the Gishwasti and Mukura forests were some of the areas partly cleared and reduced in size to build refugee camps and to resettle returnees (REMA 2009:86). About 15000 ha of forests were destroyed and 35000 ha damaged during the genocide (REMA 2009:86). Additional figures released by REMA (2009:79) indicate that forests and woodlands decreased in size by $64 \%$ to cater for the needs of the growing population and for resettlement purposes. Moreover, factors such as illegal logging and tree felling, charcoal production, agricultural practices, mining, beekeeping and bushfires have been identified to have an impact on national forest reserves (REMA 2009:79).

\section{Farming and agricultural activities}

The growth of the towns of Butare and Cyangugu after the genocide increased unemployment and people were forced into subsistence agriculture and informal activities. Subsistence agriculture was undertaken in areas surrounding houses and on the outskirts of the city (MINITERE 2001:3). Before the genocide all households from the suburbs of Butare lived off farming with related activities and more than $90 \%$ after the genocide. The only difference is that daily worker activities increased after the genocide due to lack of land for those who migrated to town. The survey results further reveal that household farming was the most important source of income before the genocide (75\%) and after the genocide households involved in farming decreased to $57 \%$ because of the scarcity of land for those migrants from rural areas who moved to the urban areas.

Additionally, due to the scarcity of agricultural land, wetlands were increasingly being used after the genocide. A survey carried out by REMA (2009:96) established that wetlands comprise approximately 165000 ha of land, 92000 ha of which are used for agricultural and fishery purposes. UNEP, UNDP and Government of Rwanda (GoR) (2007:70) have also confirmed an indiscriminate 


\section{Vadi Moodley, Alphonse Gahima and Suveshnee Munien}

conversion of wetland into agricultural fields resulting in the loss of the recharging and purifying capacity of wetlands that is essential for the survival of certain species of flora and fauna. REMA (2009:96) explained the escalation in the encroachment and use of wetlands as a 'hang-over' of the genocide caused by the limited access to resources and underdeveloped services in the country.

\section{Housing and the construction of new facilities}

The Rwandan government introduced the national human settlement policy, known as Imidugudu, in 1996 which focused on group settlement. A negative aspect of this type of housing, according to the leaders and households interviewed, was its effects on the environment. Large areas of forests were simply destroyed for resettling households. During the genocide, numerous facilities were destroyed and the construction of new facilities had serious negative effects on the environment. Forests were destroyed in some areas to create new facilities, and this led to soil erosion. In Butare and Cyangugu the interviews and observation showed that the small natural forest and woodlands decreased considerably after the genocide. Causes highlighted by respondents were: resettlement, fuel purposes, commercial purposes and construction. The main construction material after the genocide was wood. Timber and other wood products for construction contributed to deforestation in the Butare and Cyangugu areas.

\section{Fuel and energy sources and deforestation}

Deforestation has been aggravated by households seeking wood as a source of energy because they cannot afford electricity even though they live in the urban and semi-urban areas of Butare and Cyangugu. According to the majority of households surveyed (75\%), the main source of fuel was and remains wood and charcoal for cooking and lighting. Paraffin was used by $82 \%$ of households. REMA (2009:81) confirms that the structure of livelihoods of $90 \%$ of Rwandans makes forest resources such as wood the primary source of domestic energy. During the field survey, $84 \%$ of households stated that they had easy accessibility to charcoal before the genocide, but accessibility to wood sources decreased after the genocide for $67 \%$ of households. The limited access to wood sources 


\section{Environmental causes and impacts of the genocide in Rwanda}

is reinforced by the fact that reliance on charcoal as the main energy source increased from $28 \%$ before the genocide to $49 \%$ during the time of the study. Households reported that wood became scarce and expensive because of the government's environmental policy to protect forests from destruction by people using firewood and timber for cooking and building. Limited access to a basic need, coupled with the high demand may eventually lead to situations where conflicts could arise.

\section{Spread of malaria}

The primary research also shows that malaria has now become evident in Cyangugu and other areas where previously this was rare. Most leaders reported that after the genocide malaria posed a significant problem with serious consequences for much of the population. Leaders attributed the prevalence of the disease to poor environmental management and poverty. The increase in malaria spread is confirmed by PRB (2009:4) who state that the incidence rate of the disease has increased from 3,5\% in 1982 to $48 \%$ in 2003 due to environmental, health and population factors such as disease resistance, population density and population movements that have increased breeding areas for mosquitoes. The National Malaria Control Programme has been implemented in the country to combat the disease (PRB 2009:4).

\section{Conclusion}

The genocide in Rwanda was a tragedy in which over 800000 were killed. As with other genocides in the world, the one in Rwanda was complex with multidimensional causes and effects. Environmental causes, such as land scarcity, the increasing pressures of population on the land only aggravated the circumstances that led to the genocide. Severe environmental damage was caused during and after the genocide by the mass movement of refugees and the internal displacement of people. However, the most pressing environmental impact in Rwanda is increased deforestation for the purposes of housing construction, building of new facilities, the use of wood for energy and most importantly, the clearing of forested areas for agricultural purposes. Extensive deforestation has resulted in the loss of biodiversity and genetic resources. Moreover, due to 


\section{Vadi Moodley, Alphonse Gahima and Suveshnee Munien}

the limited land available, many wetlands in the country have been destroyed by misuse and soil erosion has increased through overgrazing. However, there is some hope in Rwanda. According to PRB (2009:2), the country has a national planning and policy framework, Rwanda's Vision 2020. This document discusses the interaction between population, health and the environment and recognises that the problems in the country cannot be solved in isolation. Such grand policy frameworks are common amongst most African countries, but the problem is in the implementation, especially in a country like Rwanda where there are enormous inequities and continuing mistrust in the aftermath of the genocide. Although there is a democratic government in place, this is only the starting point. The key focus should be on establishing a strong economic base so that the structures, infrastructures and superstructures of the country that were destroyed during the country can be rebuilt. The country has adopted an Economic Development and Poverty Reduction Strategy in line with its Vision 2020 (PRB 2009:2). However, there is still an over-reliance on external aid with many of the mandatory obligations. African countries, including Rwanda need to become more self-sustaining within the context of the global economy.

The country has also committed itself to reduce poverty by signing the United Nations Millennium Declaration to achieve the Millennium Development Goals (MDGs) by 2015. In order to achieve the targets set out by the MDGs, the natural increase in population needs to be reduced. Additionally, issues of population growth and redistribution are central to maintaining environmental sustainability and performance. High population densities, scarcity of natural resources, such as land, coupled with over-utilisation of existing natural resources will increase environmental degradation. A holistic and integrated approach to environmental management should be introduced, in light of the complex issues resulting from the genocide. These should include policies that introduce and facilitate the use of cost-effective alternate energy options to reduce pressures on wood and forest resources as energy sources. The relocation and redistribution of Rwandans after the genocide is a major contributing factor to current environmental pressures and issues such as the spread of malaria, which may be worsened by poor redistribution and relocation practices coupled with inadequate health facilities. A lot has been done in Rwanda to recover from 


\section{Environmental causes and impacts of the genocide in Rwanda}

the devastation of the genocide but there is still a long way to go. It is only hoped that the present generation and generations that follow will not make the same mistakes as in the past.

\section{Sources}

African Rights 1995. Rwanda, death, despair and defiance. London, African Rights.

Barnett, M.N. 2005. The UN Security Council, indifference and genocide in Rwanda. Cultural Anthropology, 12 (4), pp. 551-578.

Boudreaux, K. 2009. Land conflict and genocide in Rwanda. The Electronic Journal of Sustainable Development, 1 (3), pp. 86-95.

Butler, D. 2007. Enforced starvation: Exploring individual criminal responsibility for stateinduced famines. Available from: <http://www.nottingham.ac.uk/shared_hr/cpub/Butler. pdf. $>$ [Accessed 26 March 2007].

Calvocoressi, P. 2005. World Politics 1945-2000. London, Pearson Education.

Chalk, F.R. and K. Jonassohn 1990. The history and sociology of genocide: Analysis and case studies. New Haven, Yale University Press.

CIA (Central Intelligence Agency) 2002. The World Factbook. 2002. Introduction to Rwanda. Available from: <http://www.appliedlanguage.com/country_guides/Rwanda_country_ introduction.shtml. $>$ [Accessed 21 March 2007].

Destexhe, A. 1996. Rwanda and genocide in the twentieth century. New York, New York University Press.

Diamond, J.M. 2005. Collapse: How societies choose to fail or succeed. New York, Viking Penguin.

Ferguson, R.B. 1994. The general consequences of war: An Amazonian perspective. In: Reyna, S.P. and R.E. Downs eds. Studying war: Anthropological perspectives (War and Society). Langhome, PA, Gordon and Breach.

Fry, P.D. and K. Bjorkqvist eds. 1997. Cultural variation in conflict resolution: Alternatives to violence. Mahwah, NJ, Laurence Erlbaum Associates.

Gahima, A. 2007. The socio-economic impacts of the genocide and current developments in Rwanda: Case studies of the towns of Butare and Cyangugu. Unpublished Master's Dissertation, Department of Geography and Environmental Studies, University of KwaZulu-Natal, Durban.

IRIN (Investigator Relations Information Network) 2002. Population growth, environmental destruction and genocide. Available from: <http://medilinkz.org/news/news 2 . asp?NewsID=907>.

Jennings, C. 2001. Across the Red River, Rwanda, Burundi and the heart of darkness. London, Phoenix. 


\section{Vadi Moodley, Alphonse Gahima and Suveshnee Munien}

Karen, V.L. 1996. International dimensions of genocide. Available from: <http://www.veritnet. com/Karen/genocide.html\#cause $>$ [Accessed 20 September 2005].

Keane, F. 1995. Season of blood: A Rwandan journey. London, Penguin Books.

Laue, J.H. 1993. Resolution: Transforming conflict and violence. Occasional Paper 7. Institute for Conflict Analysis and Resolution. Fairfax, VA, George Mason University.

Mamdani, M. 2001. When victims become killers: Colonialism, nativism and the genocide in Rwanda. Princeton, Princeton University Press.

Mann, M. 2005. The dark side of democracy: Explaining ethnic cleansing. Cambridge, Cambridge University Press.

McCullum, H. 1995. The angels have left us: The Rwanda tragedy and the churches. Risk Book Series. Geneva, World Council of Churches Publications.

Melvern, L. 2000. A people betrayed: The role of the West in Rwanda's genocide. Cape Town, National Assessment of Educational Process.

MINECOFIN (Ministry of Finances and Economic Planning) 2002. Rwanda Indicators Development. Kigali, MINECOFIN.

Ministry of Infrastructures 2004. Cyangugu Master Plan. Kigali, Ministry of Infrastructures.

MINITERE (Ministry of Land, the Environment, Forest and Natural Resources) 2001. Politique nationale de l'habitat. No. 10. Kigali, MINITERE.

Muberanziza, A. 2004. Une définition juridique du génocide. Dialogue, 233, pp. 3-15.

Naimak, N.M. 2001. Fires of hatred: Ethnic cleansing in twentieth century Europe. Harvard, Harvard University Press.

Niyongabo, J. 2004. Where sustainable agriculture means agricultural productivity? The case study of Gikongoro in Southwestern Rwanda. Unpublished Master's Thesis, Department of Economic History, Lund University, Lund.

Nyankanzi, E.L. 1999. Genocide in Rwanda and Burundi. Vermont, Rochester.

Pan African News Agency 2000. Rwanda: Land scarcity may jeopardize peace process. Available from: <http://www.reliefweb.int/w/rwb.nsf.> [Accessed 5 June 2006].

Pottier, J. 2002. Re-imagining Rwanda: Conflict, survival and disinformation in the late twentieth century. Cambridge, Cambridge University Press.

PRB (Population Reference Bureau) 2009. Integrating population, health and the environment in Rwanda. Washington, DC, Population Reference Bureau.

Prunier, G. 1995. The Rwanda crisis 1959-1994, History of genocide. Kampala, Fontain.

REMA (Rwandan Environmental Management Authority) 2009. Rwanda State of the Environment and Outlook Report. Available from: <http://www.rema.gov.rw/soe> [Accessed 20 February 2010].

Robbins, S. and S. Robbins 2003. Africa, a continent in agony: We accuse! Ann Arbor, MI, Capsal. 


\section{Environmental causes and impacts of the genocide in Rwanda}

Semelin, J. 2005. Purifier et detruire: Usages politiques des massacres et genocide. Paris, Seuil.

Staub, E. 1992. Roots of evil: The origins of genocide and other group violence. Cambridge, Cambridge University Press.

Toft, D.C. 2004. The geography of ethnic violence: Identity, interests and the indivisibility of territory. Princeton, Princeton University Press.

Turshen, M. 2001. The political economy of rape: An analysis of systematic rape and sexual abuse of women during armed conflict in Africa. In: Moser, C. and F.C. Clark eds. Victims, perpetrators or actors? Gender, armed conflicts and political violence. London, Zed Books. pp. 55-68.

UNDP (United Nations Development Programme) 2003. Human development report: Human development indicators 2003. Available from: <http://www.undp.org/hdr2003/indicator/ cty_f_RWA.html $>$ [Accessed 26 March 2007].

UNEP (United Nations Environment Programme) and IISD (International Institute for Sustainable Development) 2005. Connecting poverty and ecosystem services: A series of seven country scoping studies. Focus on Rwanda. Published for UNEP by IISD, Winnipeg, Manitoba.

UNEP, UNDP and GoR (Government of Rwanda) 2007. Pilot Integrated Ecosysytem Assessment of Bugesera: Poverty and Environment Initiative Project. Rwanda Environment Management Authority.

Utterwulghe, S. 1999. Rwanda's protracted social conflict: Considering the subjective perspective in conflict resolution strategies. The online Journal of Peace and Conflict Resolution, 2 (3). Available from: <www.trinstitute.org/ojpcr/2_3.utter.htm> [Accessed 21 March 2007].

Verwimp, P. and J.V. Baval 2005. Child survival and fertility of refugees in Rwanda. European Journal of Population, 21, pp. 271-290.

World Bank 2004. Education in Rwanda: Rebalancing resources to accelerate post-conflict development and poverty reduction. London, Macmillan Press. 